\title{
AKUNTABILITAS PUBLIK PENYELENGGARAAN PARKIR TEPI JALAN UMUM DI KOTA PEKALONGAN
}

\author{
Herlambang Dwi Anggara ${ }^{1}$
}

\begin{abstract}
Accountability is a problem in many public organizations in Indonesia, including those related to parking issues. Many problems related to parking policy implementation has been faced by many local government in Indonesia. Many researches have been done on parking issues, including those related to street-side parking. However, it is found no research has been found on parking accountability. Therefore, this article is focused on research result on dtreet-side parking in Pekalongan City. The method employed is descriptive qualitative with exploratory paradigm. Is is found that based on the research results and analysis, it is found that accountability principles have not been fully applied. Only one out of four accountability principles which has met requirements, namely transparency. The supporting factors are leadership, regulations, and facilities. The inhibiting factors, however, are limited parking area, less discipline of the street parking personnel, less guidance program, and limited number of government personnels related to parking.
\end{abstract}

Keywords: public accountability, parking management, transparency, street parking, parking personnel

\section{PENDAHULUAN}

Pengukuran kinerja digunakan sebagai dasar untuk melakukan penilaian kinerja, yaitu untuk menilai sukses atau tidaknya suatu organisasi, program atau kegiatan (Mahmudi, 2015). Pengukuran kinerja pada organisasi sektor publik sangat penting untuk dibicarakan secara mendalam dan terbuka karena pengukuran yang ada di organisasi publik lebih kompleks, tidak seperti pada organisasi swasta. Salah satu dimensi atau aspek pengukurannya adalah akuntabilitas, sebagaimana dikemukakan oleh Dwiyanto (2017), bahwa penilaian kinerja harus juga dilihat dari indikator yang melekat pada pengguna jasa, seperti kepuasan pengguna jasa dan akuntabilitas.

Pada sektor publik, setiap kebijakan maupun progam kegiatan dilakukan dalam rangka memberikan pelayanan yang terbaik guna memudahkan setiap urusan masyarakat yang terkadang seringkali sulit diukur dengan ukuran finansial. Adapun di sektor swasta karena tujuan utamanya adalah mencari keuntungan atau laba maka

\footnotetext{
${ }^{1}$ ASN di Kota Pekalongan
} 
ukuran kinerjanya dapat dengan mudah diukur dengan ukuran finansial. Penyebab lain, yaitu pertanggungjawaban sektor publik tidak terbatas pada pimpinan maupun pejabat politik saja, namun juga kepada pihak-pihak yang berkepentingan. Salah satu area yang kinerjanya patut dibahas adalah instansi yang ada di Kota Pekalongan.

Kota Pekalongan yang terletak di Provinsi Jawa Tengah adalah Kota Batik yang saat sekarang sedang berkembang cukup pesat. Perkembangan yang terlihat di Kota Pekalongan adalah berupa bertambahnya pusat-pusat perbelanjaan, perkantoran serta sekolah. Selain karena potensi batik, Pekalongan juga mempunyai lokasi yang strategis, yaitu dilalui oleh jalur jalan nasional di pantai Utara Jawa. Pusat aktivitas berada hampir merata di empat Kecamatan. Akan tetapi, pusat keramaian lebih banyak di wilayah Pekalongan Timur dan Pekalongan Barat, di mana banyak terdapat pusat perbelanjaan, perkantoran dan pendidikan.

Pusat perbelanjaan seperti pertokoan, minimarket, supermarket, serta pasar tradisional selalu ramai, beraktivitas dari pagi hingga petang. Perkantoran dan pendidikan ramai pada waktu-waktu tertentu. Kunjungan masyarakat khususnya pengguna jalan pada pusat perbelanjaan dan perkantoran pasti membutuhkan tempat untuk berhentinya kendaraan, yang biasa disebut tempat parkir. Sebagai perwujudan dan konsekuensinya terhadap pelaksanaan otonomi daerah maka Pemerintah Kota Pekalongan harus bisa menata rumah tangganya sendiri serta melayani dan memenuhi kebutuhan masyarakat, demikian pula dalam hal pengelolaan perparkiran, khususnya parkir yang ada di tepi jalan umum. Perparkiran adalah salah satu permasalahan yang sering kali dialami oleh kota-kota besar yang ada di Indonesia. Masalah parkir yang tidak ditangani dengan baik dan serius dapat memperparah kemacetan arus lalu lintas, sebagaimana hasil penelitian yang dilakukan Adinugroho (2013) di kawasan Tlogosari, Kota Semarang. Dalam menangani masalah parkir, pemerintah Kota Pekalongan membuat kebijakan tersendiri mengenai perparkiran. Kota Pekalongan membentuk Peraturan Daerah Nomor 49 Tahun 2017 tentang Penyelenggaraan Parkir.

Permasalahan parkir di tepi jalan umum pada umunya dapat terjadi manakala jumlah kebutuhan parkir kendaraan lebih besar daripada kapasitas atau lahan yang dapat menampung parkir kendaraan. Kendaraan selalu melaju di setiap ruas jalan dan sewaktu-waktu akan berhenti di tempat-tempat bisnis, perkantoran, sekolah, maupun 
tempat publik lainnya. Jumlah dan kapasitas lahan parkir yang dapat menampung kendaraan selalu tetap jumlahnya. Bertambahnya kebutuhan akan area parkir kendaraan yang tanpa diimbangi dengan bertambahnya lahan parkir dapat menyebabkan kemacetan pada sebagian besar ruas jalan (Adinugraha dkk, 2013).

Permasalahan perparkiran pada tepi jalan umum yang ada di Kota Pekalongan sangat beragam. Ruas jalan perkotaan mayoritas bahu jalannya digunakan sebagai lahan parkir. Hal ini disebabkan karena pertokoan, perkantoran, sekolahan serta rumah sakit tidak cukup menyediakan lahan parkir kendaraan. Penggunaan bahu jalan hingga ke badan jalan sebagai lahan parkir tidak memperdulikan peraturan perparkiran yang sudah ditentukan sehingga membuat kemacetan arus lalu lintas yang tidak dapat dihindari. Pemakaian bahu jalan kadang bukan hanya pada satu lajur saja, bahkan terdapat lebih dari dua lajur per arah pada ruas jalan. Hal tersebut semakin parah lagi dengan banyaknya pedagang kaki lima yang berjualan di bahu jalan sehingga di beberapa ruas jalan yang ada di Kota Pekalongan semakin menyempit.

Munculnya pertokoan-pertokoan juga akan memunculkan titik-titik parkir baru yang berpotensi belum legalnya pengaturan dan pengelolaannya oleh juru parkir. Hal ini berpotensi menimbulkan penarikan atau pungutan retribusi parkir melebihi tariff yang sudah ditentukan, selain potensi besarnya hasil pungutan parker yang tidak masuk ke kas daerah, sebagaimana penelitian yang dilakukan oleh Wikaningtyas dkk, (2015) di kawasan Tembalang, Kota Semarang. Beberapa juru parkir pada titik tertentu di Pekalongan ternyata menarik uang parkir tidak sesuai dengan peraturan yang berlaku, yaitu Rp. 2.000,- untuk kendaraan bermotor roda 2 dan Rp. 3.000,- untuk kendaraan bermotor roda 4, padahal di beberapa titik tersebut terdapat papan perda parkir yang isinya berupa informasi tarif parkir kendaraan.

Pemerintah Kota Pekalongan melalui Dinas Perhubungan sudah berkali-kali melakukan pembinaan terhadap juru parkir serta masyarakat pengguna parkir kendaraan di tepi jalan umum. Pembinaan terhadap juru parkir dan masyarakat dilakukan dengan mendatangi langsung titik parkir dan memberi pengarahan aturan parkir yang benar serta menegur juru parkir yang belum melaksanakan kewajiban target pungutan retribusi. Pembinaan bagi masyarakat yang melanggar aturan parkir masih belum dilakukan penindakan atau pemberian sanksi karena aturannya belum jelas walaupun 
sarana prasarana pemberian sanksi sudah disiapkan. Oleh karena itu, hingga saat ini masih saja terdapat pelanggaran oleh oknum juru parkir maupun kurangnya kesadaran pengendara dalam memarkirkan kendaraannya.

Rendah atau belum maksimalnya akuntabilitas organisasi publik terlihat dalam penelitian yang dilakukan oleh Fajri dkk (2012) mengenai akuntabilitas pemerintah Desa Ketindan dalam mengelola ADD. Dalam kajian ini, masih ditemukan kesalahan dalam prosentase penggunaan sasaran yang tidak sesuai dengan ketentuan, meskipun pada setiap tahapan dalam melihat akuntabilitas pemerintah desa dalam pengelolaan ADD telah dilaksanakan dengan mematuhi peraturan yang ada. Belum maksimalnya akuntabilitas juga terlihat dalam penelitian yang dilakukan oleh Aprizal dan Purba (2013) mengenai akuntabilitas pelayanan publik dalam pelaksanaan program $E$ Procurement di Kota Pangkalpinang, Bangka. Dalam kajiannya dari enam indikator akuntabilitas, yaitu efisiensi, efektivitas, keadilan, transparansi, keterbukaan dan persaingan serta akuntabilitas, yang digunakan hanya indikator akuntabilitas. Hal ini menjadikan E-Procurement belum berjalan secara maksimal.

Penelitian lebih mendalam mengenai dimensi akuntabilitas juga dilakukan oleh Harsini (2018) mengenai transparansi serta faktor penghambat terciptanya transparansi pelayanan Dinas Penanaman Modal dan Pelayanan Terpadu Satu Pintu (DPMPTSP) Kota Pekanbaru. Pada kajian tersebut terlihat bahwa transparansi informasi pelayanan masih belum semuanya transparan dalam pemberian pelayanan masyarakat karena kurangnya sumber daya pada bidang pengurusan Ijin Mendirikan Bangunan. Namun berbeda dengan hasil penelitian yang dilakukan oleh Deni Triyanto (2017), yaitu kinerja BPPT Kota Semarang sudah cukup baik. Dalam dimensi akuntabilitas, BPPT Kota Semarang sudah memiliki tanggungjawab yang cukup baik karena telah tersedia LKJiP guna pertanggungjawaban kepada publik.

Penelitian-penelitian yang telah diutarakan tersebut belum mengkaji masalah akuntabilitas dilihat dari beberapa dimensi yang disertai dengan faktor pendukung dan penghambatnya. Penelitian yang dilakukan oleh Fajri dkk (2012), hanya melihat akuntabilitas dari tahapan pengelolaan ADD namun sudah terdapat faktor penghambat dan pendukungnya. Penelitian yang dilakukan oleh Aprizal dan Purba (2013) hanya melihat dan mengukur akuntabilitas dari dimensi efisiensi, efektivitas, keadilan, 
transparansi, keterbukaan dan persaingan serta akuntabel tanpa disertai faktor pendukung dan penghambatnya. Penelitian Harsini (2018) hanya mengkaji salah satu dimensi akuntabilitas, yaitu transparansi, sedangkan penelitian yang dilakukan oleh Deni Triyanto (2017) melihat akuntabilitas merupakan dimensi dari kinerja.

Berdasarkan permasalahan perparkiran yang telah diutarakan pada paragrafparagraf sebelumnya yang ada di Kota Pekalongan serta melihat dari kajian-kajian penelitian terdahulu tentang akuntabilitas, maka artikel ini mengkaji akuntabilitas penyelenggaraan parkir di tepi jalan umum dari beberapa dimensi pengukuran, serta menguraikan dan menjelaskan faktor-faktor apa saja yang menjadi pendukung serta penghambatnya. Dalam artikel ini menganalisis dimensi yang relevan dengan penelitian akuntabilitas penyelenggaraan parkir, yaitu dimensi efisiensi dan efektif, transparansi, keadilan serta responsivitas.

\section{Kerangka Pikir}

Untuk melakukan pengukuran akuntabilitas publik dan faktor-faktor yang mempengaruhi akuntabilitas organisasi sektor publik diperlukan model yang tepat dan sesuai. Dengan mempertimbangkan permasalahan dan kajian teori maka dibuat kerangka pikir untuk memahami permasalahan yang dikaji. Kerangka pikir tersebut adalah sebagai berikut: 
Identifikasi Masalah:

a. Pemakaian bahu untuk parkir dua lajur

b. Adanya parkir liar

c. Pemungutan retribusi parkir melebihi tarif seharusnya

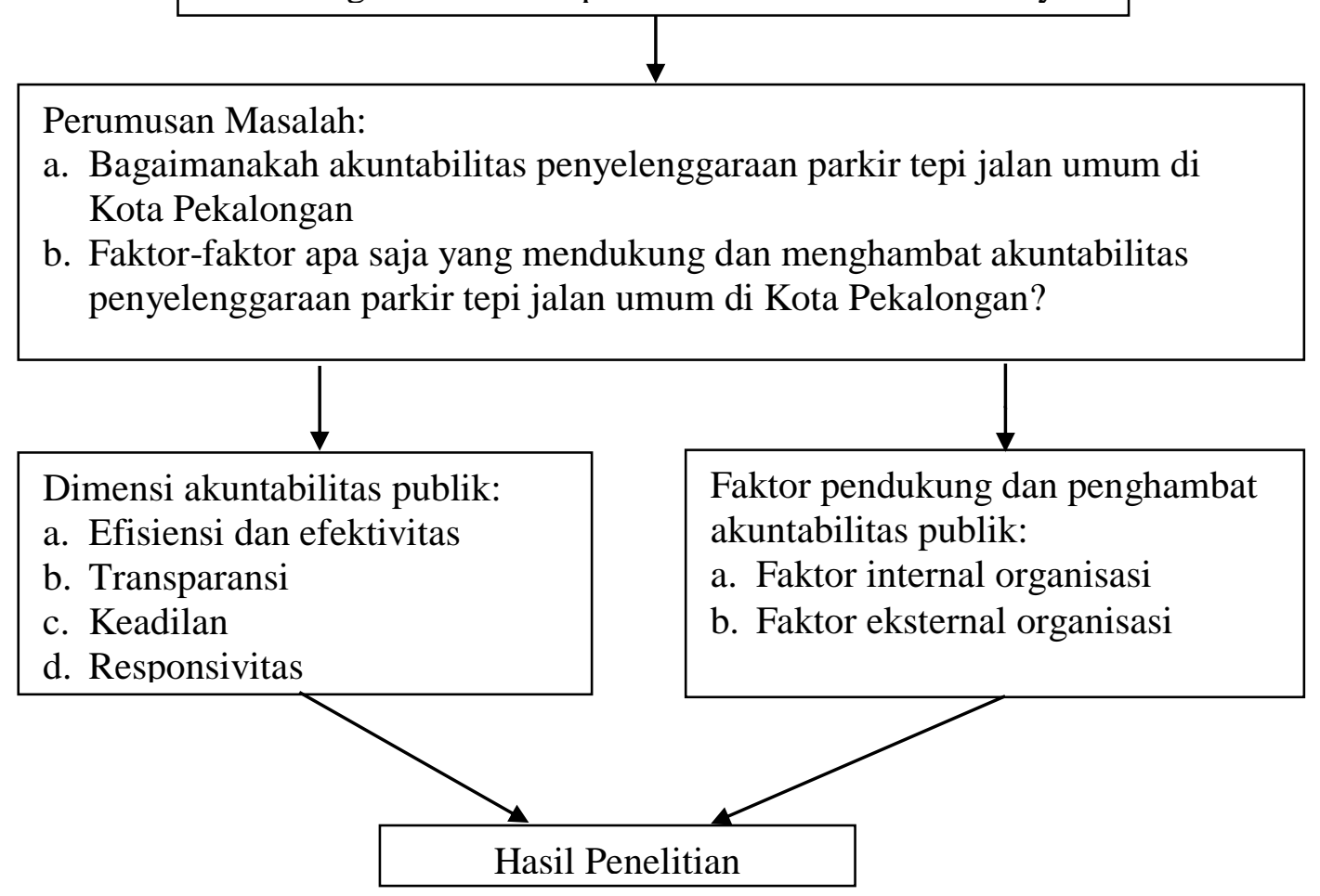

Gambar Kerangka Pemikiran Penelitian

\section{METODE PENELITIAN}

Penelitian ini menggunakan metode deskriptif kualitatif yang bersifat eksploratif agar dapat menggambarkan fakta yang sebenarnya. Fokus dari penelitian ini adalah bagaimana akuntabilitas dalam penyelenggaraan parkir di tepi jalan umum yang ada di Kota Pekalongan serta untuk mengetahui faktor-faktor apa saja yang mendukung dan menghambat akuntabilitas tersebut. Untuk sumber data, merujuk pada Lofland (dalam Moleong, 2011) sumber data utama dalam penelitian kualitatif ialah kata-kata, dan tindakan, selebihnya adalah data tambahan seperti dokumen dan lain-lain. Instrumen penelitian yang digunakan dalam mengumpulkan data adalah: peneliti sendiri, smartphone, catatan lapangan dan pedoman wawancara. Untuk proses pengumpulan data dalam penelitian ini meliputi tahapan, yakni: 1). Proses memasuki lokasi Penelitian (getting in), 2). Ketika berada dilokasi penelitian, 3). Mengumpulkan data. Adapun analisis data yang digunakan dalam penelitian ini adalah analisis model interaktif yang 
dikembangkan oleh Miles dan Huberman (dalam Sutopo, 1988) yang terdiri dari tiga komponen analisis berupa reduksi data, sajian data, dan penarikan kesimpulan.

\section{HASIL DAN PEMBAHASAN}

Akuntabilitas dalam penyelenggaraan parkir di tepi jalan umum yang ada di Kota Pekalongan dalam penelitian ini dilihat berdasarkan empat dimensi yaitu efisiensi dan efektivitas, transparansi, keadilan, serta responsivitas.

\section{Efisiensi dan Efektivitas}

Sebelum menuju pada efisiensi dan efektivitas, ada istilah dalam ekonomi yang merupakan konsep biaya untuk memperoleh suatu unit input. Konsep inilah yang hanya membicarakan mengenai input saja, yaitu bagaimana caranya memperoleh input dengan biaya yang lebih rendah sehingga biaya yang dapat ditekan maka efisiensi berarti membahas perbandingan mengenai input dengan output. Dalam konteks sektor publik, efisiensi berarti pelayanan yang dihasilkan dengan sumber daya yang digunakan untuk menghasilkan output (Aprizal dkk, 2013). Efisiensi dapat terjadi jika penyelenggara layanan mampu meminimalkan biaya yang tidak diperlukan untuk melakukan kegiatan pelayanan dalam setiap penyelenggaraan kegiatan pelayanan yang dilakukan oleh organisasi sektor publik. Dalam konteks sektor publik, efektivitas berarti output berupa pelayanan yang dihasilkan dapat memenuhi tujuan organisasi yang telah diharapkan. Efektivitas itu sendiri merupakan hubungan antara output dengan tujuan yang juga merupakan kaitan hubungan antara hasil yang diharapkan dengan hasil yang sesungguhnya telah dicapai. Dalam penelitian ini, prinsip efisiensi dan efektivitas dapat dilihat dari besar kecilnya anggaran, kemanfaatan penggunaan anggaran, kemanfaatan penggunaan peralatan penunjang kegiatan.

Besar kecilnya anggaran untuk kegiatan dalam rangka menyelenggarakan parkir di tepi jalan umum yang tertuang dalam DPA Dinas Perhubungan Kota Pekalongan tahun anggaran 2019 adalah sebesar Rp. 315.350.000,-. Anggaran tersebut untuk sosialisasi dan pembinaan kepada juru parkir serta atribut juru parkir dalam mengelola parkir tepi jalan umum. Berdasarkan wawancara mendalam, dapat disimpulkan bahwa besarnya anggaran sosialisasi dan pembinaan kepada juru parkir masih belum dapat menciptakan budaya tertib parkir kendaraan bermotor karena kemanfaatan penggunaan anggaran yang tersedia hanya untuk pembinaan kepada juru parkir. Anggaran kegiatan 
untuk sosialisasi dan pembinaan kepada juru parkir di dalam DPA Tahun Anggaran 2019 berisi tentang honor dan bantuan transport petugas serta belanja atribut parkir. Berdasarkan wawancara mendalam, kemanfaatan penggunaan anggaran sebenarnya masih dapat diatur dan dikelola dengan optimal.

Menurut Kasie Pembinaan Lalu Lintas, "Selama ini, kegiatan yang kita lakukan hanya untuk pemberian honor dan bantuan transport petugas penagihan retribusi kepada juru parkir dan pembinaan kepada juru parkir tentang penataan parkir saja mas, selain itu juga ada belanja pakaian kerja untuk juru parkir dan atributnya". Hal ini berarti, kegiatan sosialisasi dan pembinaan kepada juru parkir hanya sebatas kepada juru parkir saja. Padahal untuk menciptakan budaya tertib parkir tidak hanya dari juru parkirnya saja, tetapi juga dari pengguna jasa parkirnya. Penggunaan peralatan penunjang kegiatan penertiban parkir yang ada di Dinas Perhubungan Kota Pekalongan berupa mobil derek dan gembok parkir masih sangat belum optimal.

Berdasarkan pengamatan penulis dan hasil wawancara mendalam, mobil derek dan gembok parkir belum pernah digunakan untuk penertiban parkir. Padahal penggunaan kedua alat tersebut dapat menimbulkan efek jera kepada pelanggar parkir tepi jalan umum. Tidak digunakannya mobil derek karena ukuran mobil derek yang terlalu besar sehingga akan menyulitkan petugas dan dapat menimbulkan kemacetan. Terlalu besarnya ukuran armada derek ini ternyata pada tahun 2016 terjadi kekeliruan pengadaan yaitu ketidaktahuan dimensi atau ukuran mobil akibat pembelian mobil derek karena melalui e-purchasing.

\section{Transparansi}

Dalam konteks akuntabilitas, transparansi dapat diartikan sebagai mudahnya akses untuk mendapatkan informasi yang berhubungan dengan fungsi dan kinerja dari instansi/organisasi (Wicaksono, 2015). Pada umumnya, persoalan mendasar yang dihadapi oleh pemerintah terkait optimalisasi pelayanan publik adalah rendahnya kesadaran pemerintah atau pihak-pihak yang bekerja sama dengan pemerintah terkait transparansi dalam penyelenggaraan layanan publik itu sendiri. Padahal, organisasi pemerintah diharapkan untuk selalu mengkomunikasikan fungsi dan kinerjanya kepada pihak-pihak yang berkepentingan sehingga akan diketahui fungsinya dan dapat dinilai kinerjanya. Hal-hal yang seringkali disoroti adalah belum terbukanya sistem 
penyelenggaraan layanan publik yang dapat memberikan kemudahan bagi masyarakat dalam mengakses berbagai program dan kebijakan pemerintah, termasuk bagaimana sistem kerja sama pemerintah dengan sektor swasta dalam penyelenggaraan parkir tepi jalan umum seperti di Kota Pekalongan ini.

Keterbukaan pemerintahan di era sekarang ini sudah menjadi keharusan karena ada perintah undang-undang yang harus ditaati, yaitu undang-undang keterbukaan informasi publik. Hal ini mengisyaratkan bahwa setiap program kegiatan yang dilakukan oleh organisasi pemerintah atau publik haruslah mudah diakses oleh masyarakat. Keterbukaan juga dilakukan oleh pemerintah sebagai pelayan masyarakat dalam melaksanakan proses penyelenggaraan pelayanan sehingga masyarakat mengetahui proses tersebut (Irawan, 2018). Hal tersebut bertujuan agar tercipta paradigma baru pemerintahan yang semula selalu kaku dan tertutup, menjadi tata kelola pemerintahana yang terbuka dan pada akhirnya akan mengubah wajah tata kelola pemerintahan yang terbuka.

Peraturan Daerah Kota Pekalongan Nomor 1 Tahun 2017 tentang Perubahan Atas Peraturan Daerah Nomor 21 Tahun 2011 Tentang Retribusi Pelayanan Parkir di Tepi Jalan Umum juga mengamanatkan mengenai keterbukaan informasi, khususnya persoalan keterbukaan tarif retribusi parkir yang dikenakan pada pengguna jasa parkir tepi jalan umum. Hal ini dapat diketahui dengan terdapatnya papan Perda parkir yang dipasang di beberapa titik atau pusat keramaian. Akan tetapi menurut hasil wawancara mendalam dan pengamatan penulis, pemasangan papan Perda parkir masih tidak strategis, yaitu terlalu tinggi tiangnya dan tampilannya kurang menarik sehingga masyarakat kesulitan membacanya. Jumlah papan Perda parkir masih mencukupi mengingat hanya di beberapa titik parkir saja yang para juru parkirnya memungut retribusi melebihi ketentuan.

Dinas Perhubungan Kota Pekalongan mempunyai website serta akun di media sosial. Hal ini disediakan untuk memudahkan dalam memberikan informasi pelayanan, informasi kegiatan, berinteraksi serta menerima kritik dan saran. Selain itu, terdapat petugas yang selalu ada di ruang kerja atau ruang pelayanan untuk melayani juru parkir maupun masyarakat. Transparansi ini tentu saja memiliki implikasi yang positif untuk penataan pelayanan parkir yang ada. Dimana transparansi tentu akan memudahkan 
masyarakat dalam "pemakluman" segala kondisi dan keterbatasan pemerintah, serta sarana dan prasarana parkir itu sendiri. Dengan transparansi ini juga akan menciptakan keadaan yang memberikan dorongan bagi juru parkir agar dapat senantiasa selalu kompetitif dalam memberikan pelayanan parkir kepada pengguna jasa parkir. Hal ini tentu saja positif untuk mencapai target yang telah di tentukan oleh DPRD Kota Pekalongan. Hal ini tentu saja akan menguntungkan masyarakat dengan semakin membaiknya pelayanan parkir tepi jalan yang diadakan. Pada akhirnya, indikasi dari konsep transparansi selama ini dapat dilakukan dengan baik. Meskipun masih harus diberikan catatan mengenai tampilan dan posisi peletakan papan perda parkir tepi jalan umum.

\section{Keadilan}

Pada dasarnya, salah satu tujuan dari program kegiatan peningkatan kualitas pelayanan publik adalah untuk memenuhi rasa keadilan khususnya kepada masyarakat dan pada akhirnya mendorong partisipasi dan pemberdayaan masyarakat itu sendiri. Prinsip adil dalam penyelenggaraan pelayanan itu bisa diartikan juga tindakan yang tidak diskriminatif, tidak membeda-bedakan yang dilakukan oleh organisasi publik dalam setiap pelayanannya. Mengacu pada penelitian ini, keadilan yang dimaksud tentu lebih kepada besaran pungutan tarif retribusi yang telah ditetapkan oleh pemerintah kepada pengguna jasa layanan parkir yang dalam hal ini adalah masyarakat di samping adanya besaran pungutan retribusi, keadilan juga dimaksudkan dalam hal penertiban parkir oleh petugas yang tidak pandang bulu antar titik parkir.

Kebijakan parkir di tepi jalan umum yang ada di Kota Pekalongan mengatur tentang besarnya tarif retribusi parkir. Hal ini terdapat pada Lampiran Perda Nomor 1 Tahun 2017. Meskipun tarif retribusi sudah diatur dalam Perda serta terdapat papan parkir, namun di beberapa titik parkir masih terdapat pungutan parkir melebihi tarif atau ketentuan. Dari hasil wawancara mendalam dengan narasumber (pengguna parkir dan juru parkir), dapat disimpulkan bahwa juru parkir memungut retribusi untuk kendaraan roda dua dibarengi dengan dalih/alasan sekalian titipan helm, sedangkan masyarakat pengguna jasa parkir, enggan untuk mempermasalahkan nominal yang dipungut oleh juru parkir. 
Pada dimensi keadilan juga ditunjukkan oleh Petugas gabungan dari Dinas Perhubungan, TNI, Polisi serta Satpol PP rutin melakukan penertiban dan parkir. Penertiban dan pembinaan parkir dititikberatkan pada titik parkir berupa kegiatan sosialisasi ringan dan sederhana kepada juru parkir dan masyarakat. Hal ini untuk memberikan jaminan tarif parkir yang sama di semua titik parkir seperti yang diungkapkan oleh Kasie Pembinaan Lalu Lintas, "Upaya penertiban pada juru parkir agar juru parkir memungut retribusi parkir sesuai peraturan". Tindakan pemberian peringatan kepada juru parkir yang melanggar juga dilakukan namun tidak dilakukan pemberian sanksi berupa pencabutan ijin. Akan tetapi, tindakan pungutan melebihi tarif parkir masih dilakukan oleh juru parkir di titik parkir tententu. Jadi untuk tercapainya akuntabilitas publik dalam penyelenggaraan parkir di tepi jalan umum, dimensi keadilan harus menjadi pertimbangan yang penting karena pada prakteknya di lapangan, cukup banyak praktek-praktek parkir yang melaksanakan retribusi yang tidak wajar. Ada harga yang terlalu tinggi, ada juga pelayanan yang tidak memadai dan terkesan "pemalakan" oleh oknum juru parkir dan lain sebagainya.

\section{Responsivitas}

Responsivitas merupakan konsep yang digunakan sebagai pengukuran kinerja pelayanan publik. Responsivitas sangat diperlukan dalam pelayanan publik karena hal tersebut merupakan bukti kemampuan organisasi untuk mengenali kebutuhan masyarakat, menyusun agenda dan prioritas pelayanan serta mengembangkan programprogram pelayanan publik sesuai dengan kebutuhan dan aspirasi masyarakat (Dwiyanto, 2017). Dalam akuntabilitas, dimensi responsivitas dianggap penting. Hal ini karena perlu diketahui dan disadari bersama bahwa organisasi publik atau instansi pemerintah pada dasarnya didirikan untuk mensejahterakan masyarakat. Bentuk nyata dari mensejahterakan adalah organisasi publik dapat menjawab serta menyediakan kebutuhan dan permintaan masyarakat dengan cepat dan tanggap, seperti yang dikemukakan oleh Harsini (2018) bahwa diperlukan pemerintah yang responsif terhadap segala kebutuhan pelayanan publik yang diinginkan masyarakat. Oleh karenanya kehadiran organisasi publik di tengah-tengah masyarakat tentunya sangat bergantung pada bagaimana responsivitas penyelenggara organisasi publik. Disamping itu, responsivitas tidak hanya menyangkut pada penanganan masalah kebutuhan yang telah 
ada, namun juga kemampuannya dalam mengantisipasi munculnya permasalahan kebutuhan baru di masa depan

Penggunaan bahu jalan untuk lahan parkir masih banyak dijumpai. Penggunaan bahu jalan hingga ke badan jalan sebagai lahan parkir tidak memperdulikan peraturan perparkiran yang sudah ditentukan sehingga membuat kemacetan arus lalu lintas. Persoalannya tidak berhenti sampai di situ saja bahkan terdapat lebih dari dua lajur per arah yang kemudian digunakan sebagai lahan parkir. Sikap masyarakat pengguna jasa parkir tepi jalan umum juga seenaknya dalam memarkirkan kendaraanya selagi dekat dengan tempat yang dituju. Persoalan lain, yaitu juru parkir di beberapa titik parkir memungut retribusi parkir melebihi ketentuan.

Dengan masih adanya persoalan-persoalan tersebut, Dinas Perhubungan Kota Pekalongan masih kurang menunjukkan responsivitas dalam menertibkan parkir sembarangan serta juru parkir yang memungut melebihi ketentuan. Meskipun di beberapa waktu pernah dilakukan penertiban parkir sembarangan, namun hal itu pada saat-saat tertentu seperti menjelang Idul Fitri. Dinas Perhubungan juga dinilai kurang tegas dalam menertibkan titik parkir yang melanggar ketentuan karena ulah juru parkir.

\section{Faktor Pendukung Dan Penghambat Akuntabilitas Publik Dalam}

\section{Penyelenggaraan Parkir Tepi Jalan Umum Di Kota Pekalongan}

\section{Faktor Pendukung (Internal)}

\section{a. Faktor Kepemimpinan}

Kepemimpinan yang memiliki responsibility dan memiliki komitmen, serta mampu memotivasi bawahannya, tentu akan menghasilkan kebijakan dan penerapan kebijakan yang baik pula. Dalam kondisi di lapangan kepemimpinan menjadi faktor pendukung kinerja organisasi. Hal tersebut karena dalam memberikan arahan dan proses pengambilan keputusan khususnya dalam perparkiran bersifat bottom up, yaitu dengan selalu melibatkan bawahannya sehingga keputusan yang diambil merupakan hasil dari diskusi yang disepakati bersama. Ketegasan dalam perencanaan pengaturan parkir tepi jalan umum sering ditunjukkan oleh Kepala Dinas Perhubungan Kota Pekalongan pada saat rapat maupun apel pagi. Pimpinan selalu menghendaki agar dalam pengaturan parkir tepi jalan umum berkoordinasi dengan 
Seksi terkait maupun dengan instansi lain. Hal ini memberikan dorongan semangat bagi pelaksana dalam menjalankan tugas.

\section{b. Regulasi}

Pada tataran konsep dan regulasi, pelaksanaan parkir tepi jalan umum di Kota Pekalongan seharusnya tidak ada lagi masalah karena pemerintah kota telah memiliki regulasi yang mengurus khusus tentang pelaksanaan parkir tepi jalan umum. Kota Pekalongan membentuk Peraturan Daerah Nomor 16 Tahun 2016 tentang Penyelenggaraan Parkir: 1) terwujudnya pelayanan parkir yang aman, tertib, lancar dan terpadu dengan pusat kegiatan dan/atau angkutan jalan, 2) terwujudnya penyelenggaraan pelayanan parkir yang layak sesuai dengan ketentuan perundangundangan, 3) terwujudnya perlindungan dan kepastian hukum dalam penyelenggaraan perparkiran, dan 4) terwujudnya tertib lalu lintas dan angkutan jalan. Adanya regulasi yang telah dibuat, tentu menjadi kekuatan yang positif bagi semua pihak untuk menyelenggarakan parkit tepi jalan umum.

c. Sarana Prasarana

Beberapa peralatan dan perlengkapan pendukung pelaksanaan kegiatan perparkiran tersedia dengan baik. Peralatan dan perlengkapan meliputi tersedianya kendaraan operasional parkir, gembok parkir hingga mobil derek dapat digunakan oleh petugas. Pemanfaatan kendaraan operasional parkir digunakan oleh petugas dalam upaya penertiban dan pembinaan parkir. Pemanfaatan gembok parkir masih menunggu peraturan Walikota, sedangkan pemanfaatan mobil derek selama ini masih sebatas untuk angkut rambu pengaturan dan penertiban parkir serta patroli dengan tujuan membuat efek takut bagi pelanggar parkir. Petugas juga dibekali dengan kelengkapan penertiban parkir.

\section{Faktor Penghambat}

a. Kondisi Lingkungan (Kurangnya lahan parkir)

Dibeberapa lokasi keramaian di Kota Pekalongan memiliki ruas jalan yang cukup sempit dan juga sangat sedikit dengan lahan parkir. Misalnya Jalan Hasanudin yang ada di Kota Pekalongan merupakan jalan satu arah di mana pada ruas jalan tersebut terdapat pertokoan dan perkantoran yang selalu ramai dikunjungi masyarakat, selain banyak pedagang kaki lima yang berjualan di tepi jalan. Lahan 
parkir tidak disediakan oleh para pemilik toko sehingga masyarakat menggunakan tepi jalan hingga pada dua sisi untuk memarkirkan kendaraannya. Hal ini membuat badan jalan menyempit dan menimbulkan kepadatan arus lalu lintas.

Selain itu juga ada jalan Bandung merupakan jalan satu arah terdapat rumah sakit dan beberapa pertokoan. Kapasitas lahan parkir pengunjung rumah sakit untuk menampung kendaraan sangat terbatas sehingga pengunjung rumah sakit menggunakan tepi jalan untuk memarkirkan kendaraannya. Beberapa pertokoan letaknya dekat dengan traffic light dan pengunjung toko memarkirkan kendaraannya dekat dengan traffic light yang dapat mengakibatkan penyempitan jalan. Hal ini dapat menimbulkan kepadatan dan kemacetan arus lalu lintas.

b. Juru Parkir

Kurangnya lahan atau tempat parkir dapat memunculkan dan menyuburkan parkir liar di Kota Pekalongan. Bertambahnya pusat perbelanjaan dan pusat kuliner yang pesat maka kebutuhan pengguna jasa parker untuk memarkir kendaraannya juga semakin bertambah. Hal ini memunculkan juru parkir dan titik parkir baru yang tidak mempunyai legalitas. Munculnya juru parkir liar yang ditandai dengan tidak lengkapnya atribut juru parkir yang telah diatur dalam Perda juga terdapat pada beberapa titik parkir yang telah ditetapkan sebagai titik parkir. Juru parkir di beberapa titik parkir memungut retribusi parkir melebihi ketentuan, yaitu kendaraan roda 2 sebesar Rp. 2.000,- dan roda 4 sebesar Rp. 3.000,-, padahal di Peraturan Daerah Kota Pekalongan Nomor 1 Tahun 2017 tentang Retribusi Pelayanan Parkir di Tepi Jalan Umum mengatur bahwa tarif parkir di tepi jalan umum untuk kendaraan roda 2 sebesar Rp. 1.000,- dan kendaraan roda 4 sebesar Rp. 2.000,-. Beberapa hambatan dari juru parkir yang dijelaskan tersebut adalah gambaran bahwa tingkat akuntabilitas Dinas Perhubungan Kota Pekalongan dalam penyelengganaan parkir tepi jalan umum masih rendah.

c. Kegiatan Pembinaan (Kurangnya Pembinaan Juru Parkir)

Seksi Pembinaan Lalu Lintas pada Bidang Lalu Lintas Dinas Perhubungan Kota Pekalongan mempunyai fungsi pelaksanaan penyuluhan dan pembinaan tertib lalu lintas serta mempunyai tugas merencanakan dan melaksanakan kegiatan pembinaan terhadap pengguna jalan dan urusan pengelolaan perparkiran tepi jalan dalam tertib 
berlalulintas sehingga faktor keselamatan, keamanan dan kenyamanan pengguna jalan akan lebih terjamin. Dalam tugas pokok dan fungsinya tersebut, Seksi Pembinaan Lalu Lintas berperan aktif dalam pengelolaan penyelenggaraan parkir khususnya parkir di tepi jalan umum. Namun pada kenyataannya, hingga hari ini masih juga ada parkir liar yang belum teratasi serta ulah juru parkir yang memungut retribusi parkir melebihi ketentuan peraturan yang berlaku. Selain itu juga banyaknya juru parkir yang tidak memberikan karcis retribusi kepada pengguna jasa parkir. Hal ini tentu saja menyalahi aturan dengan penyelewengan hasil retribusi yang seharusnya dilaporkan oleh setiap juru parkir.

\section{d. Kurangnya SDM}

Sumberdaya manusia merupakan aspek terpenting dalam pencapaian kinerja organisasi. Sumberdaya manusia yang memiliki kualitas dan kuantitas sangatlah dibutuhkan dalam akuntabilitas publik. Berdasarkan kondisi di lapangan sumberdaya manusia menjadi aspek penghambat akuntabilitas. Hal ini karena kuantitas dan kualitas pegawai yang dimiliki belum memadai. Jumlah petugas yang ada pada Seksi Pembinaan Lalu Lintas tidak mencukupi untuk menangani perparkiran yang ada di lapangan. Oleh karena itu pada kegiatan-kegiatan penertiban harus dibantu dari Seksi lain dan petugas di luar instansi. Meskipun sudah dibantu dari Seksi dan Instansi lain, namun masih banyak yang parkir sembarangan. Hal ini berarti bahwa pengawasan terhadap juru parkir serta masyarakat pengguna jasa parkir masih lemah.

\section{PENUTUP}

\section{Kesimpulan}

Berdasarkan hasil penelitian dan pembahasan mengenai akuntabilitas publik penyelenggaraan parkir di tepi jalan umum di Kota Pekalongan, dari hasil analisis terhadap 4 indikator akuntabilitas publik, yakni efisiensi dan efektivitas, transparansi, keadilan, dan responsivitas disimpulkan bahwa akuntabilitas publik dalam penyelenggaraan parkir tepi jalan umum di Kota Pekalongan masih belum optimal.

Pertama, efisiensi dan efektivitas masih sangat rendah. Hal ini karena besarnya anggaran sosialisasi dan pembinaan kepada juru parkir masih belum dapat menciptakan budaya tertib parkir kendaraan bermotor. Kemanfaatan penggunaan anggaran yang 
tersedia hanya untuk pembinaan kepada juru parkir sehingga untuk melengkapi segala sarana dan prasarana yang seharusnya ada pada akhirnya tidak maksimal.

Kedua, hal-hal yang seringkali disoroti pada dimensi transparansi adalah kemudahan memberikan informasi, kemudahan akses serta kemudahan berinteraksi. Pada dimensi ini, akuntabilitas publik sudah baik. Hal ini terlihat dari adanya papan perda parkir yang memberikan informasi mengenai tarif retribusi parkir tepi jalan umum, adanya website instansi dan akun media sosial yang memudahkan masyarakat mengakses segala informasi berbagai program dan kebijakan pemerintah. Dengan adanya transparansi juga membuat para juru parkir saling berlomba dalam memberikan pelayanan yang baik kepada masyarakat pengguna parkir.

Ketiga, untuk dimensi keadilan pada penelitian ini adalah keadilan kepada besaran tarif retribusi yang ditetapkan oleh pemerintah dan pihak swasta kepada pengguna jasa layanan parkir yang dalam hal ini adalah masyarakat. Pada tahap konsep, sistem pelayanan dan retribusi yang dikenakan pada masyarakat telah dibuat dalam peraturan daerah, namun praktek di lapangan, masih terjadi pemungutan biaya parkir yang merusak rasa keadilan masyarakat. Mulai dari retribusi yang tidak sesuai aturan pemerintah serta minimnya fasilitas yang disipakan oleh pemerintah.

Keempat, tingkat akuntabilitas Dinas Perhubungan Kota Pekalongan khususnya terkait dimensi responsivitas dalam penyelengganaan parkir tepi jalan umum masih rendah. Hal ini terlihat pada beberapa ruas jalan yang trotoar dan bahu jalannya digunakan untuk parkir kendaraan dengan seenaknya. Juru parkir di beberapa titik parkir juga masih memungut retribusi parkir melebihi ketentuan. Dengan demikian bahwa sikap petugas kurang sigap dalam menertibkan parkir.

Faktor pendukung akuntabilitas publik terlihat dari beberapa aspek: a). Faktor kepemimpinan yang berkomitmen serta tegas, secara garis intruksional komando yang diberikan sebenarnya sudah baik, namun pada prakteknya terkadang cukup lemah karena kompleknya persoalan di lapangan. b). Faktor pendukung yang kedua terlihat adanya regulasi yang memayungi aktifitas perparkiran tepi jalan umum ini, di mana para petugas tinggal melaksanakannya saja sesuai dengan tupoksi dan kebijakankebijakan penyelenggaraan parkir tepi jalan umum. c). Faktor pendukung ketiga, yaitu adanya sarana prasarana yang memadai. Beberapa peralatan dan perlengkapan dalam 
melakukan penertiban parkir tepi jalan umum serta pembinaan/sosialisasi baik kepada juru parkir dan masyarakat tersedia dengan baik.

Adapun faktor penghambat terdiri dari beberapa hal; a). Kurangnya lahan parkir, yang disebabkan oleh minimnya tempat atau lahan parkir yang disediakan oleh pemilik toko sehingga masyarakat menggunakan tepi jalan hingga pada dua sisi untuk memarkirkan kendaraannya. b). Juru Parkir, yang tanpa ijin resmi sebagai akibat dari munculnya pertokoan baru, juga ulah oknum yang menarik retribusi melebihi ketentuan; c). Kegiatan Pembinaan; dengan ditandai masih banyaknya praktek perparkiran yang tidak semestinya dan menyalahi aturan, mulai dari lokasi hingga tidak diberikannya karcis retribusi kepada pengguna jasa parkir; d). Kurangnya SDM, yaitu kualitas dan kuantitas pegawai/petugas belum memadai yang ditandai dengan masih banyaknya parkir kendaraan dengan seenaknya.

\section{Saran}

1. Kecermatan serta skala prioritas dalam penganggaran. Hendaknya pihak instansi lebih mencermati dalam membuat pos anggaran belanja yang berhubungan dan memiliki manfaat langsung pada masyarakat.

2. Peningkatan transparansi dengan selalu memperbaharui website baik itu isinya maupun tampilannya. Perbaharuan papan perda parkir juga hendaknya rutin dilakukan serta dibuat agar lebih menarik dan informatif serta mudah dibaca oleh masyarakat pengguna parkir.

3. Hendaknya selalu dilakukan kerjasama dan koordinasi dengan Satuan Reserse Kriminal dan Satuan Lalu Lintas Polres Pekalongan Kota dalam kegiatan rutin penertiban serta penindakan oknum juru parkir agar pemungutan tarif sesuai dengan ketentuan.

4. Hendaknya peraturan Walikota mengenai petunjuk pelaksana teknis penggunaan gembok parkir dan mobil derek segera dibuat dan disosialisasikan agar penertiban serta penindakan pelanggaran parkir dapat lebih optimal.

\section{DAFTAR PUSTAKA}

Adinugraha, YK, H. Purnaweni, A. Rengga. 2013. Implementasi Peraturan Daerah No.11 Tahun 2000 Tentang Pengaturan dan Pembinaan Pedagang Kaki Lima di Kawasan Tlogosari Semarang. Journal of Public Policy and Management Review, Vol.1 No.1, hlm 1-10. 
Aman, A., Al-Shbail, T. A., and Mohammed, Z. 2013. Enhancing public organizations accountability through E-Government systems. International Journal of Conceptions on Management and Social Sciences.

Aprizal, \& Purba, J. R. T. 2013. Akuntabilitas Pelayanan Publik dalam Pelaksanaan EProcurement di Kota Pangkalpinang. JKAP (Jurnal Kebijakan Dan Administrasi Publik).

Budiman, A. A. 2016. Akuntabilitas Lembaga Pengelola Wakaf. Walisongo: Jurnal Penelitian Sosial Keagamaan. https://doi.org/10.21580/ws.2011.19.1.213

Dan, M., \& Rusli, Z. 2013. Akuntabilitas Pelayanan Publik. Jurnal Administrasi Pembangunan.

Dwiyanto, Agus., dkk. 2017. Reformasi Birokrasi Publik di Indonesia. Yogyakarta : Gadjah Mada Universitas Press.

Fajri, R., Setyowati, E., \& Siswidiyanto. 2012. Akuntabilitas Pemerintah Desa Pada Pengelolaan Alokasi dana Desa (ADD) (Studi pada Kantor Desa Ketindan , Kecamatan Lawang , Kabupaten Malang). Jurnal Administrasi Publik (JAP).

Faradhiba, L., \& Diana, N. 2018. Akuntabilitas Pemerintah Desa dalam Pengelolaan Anggaran Pendapatan dan Belanja Desa (APBDES). E-JRA Vol. 07 No. 01 Agustus 2018. https://doi.org/10.1186/1476-4598-10-45

Harsini, H. 2018. Transparansi Pelayanan Publik Pada Dinas Penanaman Modal Dan Pelayanan Terpadu Satu Pintu (DPMPTSP) Kota Pekanbaru. Jurnal Niara. https://doi.org/10.31849/nia.v10i2.1903.

Hasrina, C. D., Yusri, Y., \& Sy, D. R. A. S. 2019. Pengaruh Akuntabilitas dan Transparansi Lembaga Zakat Terhadap Tingkat Kepercayaan Muzakki Dalam Membayar Zakat Di Baitul Mal Kota Banda Aceh. Jurnal Humaniora : Jurnal Ilmu Sosial, Ekonomi Dan Hukum. https://doi.org/10.30601/humaniora.v2i1.48

Irawan, A. 2018. Transparansi Pelayanan Publik Pada Dinas Penanaman Modal Dan Pelayanan Terpadu Satu Pintu (DPMPTSP). Jurnal Politik dan Sosial Kemasyarakatan, Vol. 10 No. 3.

Mahmudi. 2015. Manajemen Kinerja Sektor Publik Edisi Kedua. Yogyakarta: UPP STIM YKPN.

Mahsun, Mohamad. 2013. Pengukuran Kinerja Sektor Publik : Cetakan Pertama. Yogyakarta : Penerbit BPFE-Yogyakarta.

Moleong, L.J. 2011. Metodologi Penelitian Kualitatif Edisi Revisi. Bandung: PT Remaja Rosdakarya

Pemerintah Republik Indonesia, 2015, Undang-Undang Nomor 9 Tahun 2015 Tentang Perubahan Kedua Atas Undang-Undang Nomr 23 Tahun 2014 Tentang Pemerintahan Daerah

Pemerintah Kota Pekalongan, 2016, Peraturan Daerah Nomor 16 Tahun 2016 Tentang Penyelenggaraan Parkir 
Ratminto dan Atik Septi Winarsih. 2016. Manajemen pelayanan. Yogyakarta: Pustaka Pelajar

Riyanto, T. 2015. Akuntabilitas Finansial Dalam Pengelolaan Alokasi Dana Desa (ADD) Di Kantor Desa Perangat Selatan Kecamatan Marangkayu Kabupaten Kutai Kartanegara. EJournal Administrasi Negara.

Sedarmayanti. 2017. Manajemen Sumber Daya Manusia. Bandung: Refika Aditama

Sulistiyani, A.T dan Rosidah. 2016. Manajemen Sumber Daya Manusia. Yogyakarta: Graha Ilmu.

Siagian, Sondang, P. 2008. Manajemen Sumber Daya Manusia (Edisi Pertama). Jakarta: Binapura Aksara

Triyanto, D. 2017. Analisis Kinerja Organisasi Dalam Mewujudkan Pelayanan Prima Kepada Masyarakat (Studi Pada Kantor Badan Pelayanan Perizinan Terpadu Kota Semarang). Jurnal Penelitian Sosial dan Politik. Vol. 6 No. 4.

Wicaksono, K. W. 2016. Akuntabilitas Organisasi Sektor Publik. JKAP (Jurnal Kebijakan Dan Administrasi Publik). https://doi.org/10.22146/jkap.752

Wikaningtyas, A.H, Kismartini, H Purnaweni, 2015, Implementasi Peraturan Daerah No. 2 Tahun 2012 Tentang Retribusi Parkir di Tepi Jalan Umum di Kawasan Tembalang, Journal of Public Policy and Management Review, Vol. 4, No. 3, halaman 288-300. 